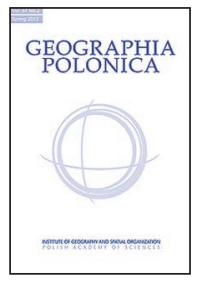

\title{
THE PERCEPTION OF BIHOR MOUNTAIN TOURIST DESTINATION, ROMANIA
}

\section{Grigore Vasile Herman ${ }^{1}$ (D) - Norbert Banto ${ }^{2}$ (D) - Tudor Caciora ${ }^{1}$ (D) • Mihaela Ungureanu ${ }^{1,2}$ (D) Sorin Furdui ${ }^{1,2}$ (D) - Lavinia Daiana Garai ${ }^{1}$ (D) Vasile Grama ${ }^{1}$ iD}

${ }^{1}$ Faculty of Geography, Tourism and Sport University of Oradea University Street 1, Oradea, 410 087: Romania e-mails: grigoreherman@yahoo.com (corresponding author)・vasile.grama2014@gmail.com tudor.caciora@yahoo.com・umihaela59@yahoo.com • sorin1182@yahoo.com・ daianagarai@yahoo.com

${ }^{2}$ Bihor Destination Management Agency

Primăriei Street 2, Oradea: Romania

e-mails: bnorbert24@yahoo.com・umihaela59@yahoo.com・sorin1182@yahoo.com

\begin{abstract}
Tourism represents one of the economic sectors with major implications in the sustainable development of the mountain areas. The tourists' perception regarding the image of the tourist destinations is a key requirement that all the stakeholders in tourism have to take into account, due to its major role in shaping and directing the tourist flows and in the development of local communities, by extension. In terms of methodology, the questionnaire method was used in this study, with a face-to-face implementation technique. Among others, the questionnaire had targeted the degree of knowledge concerning Bihor Mountain destination, the tourist consumer habits and the tourists' perception related to the quality-price ratio because of tourist consumption. The results show that most of the respondents have stated that they have not visited Bihor Mountain Tourist Destination for the first time, coming back here even several times a year because of its multiple tourist attractions and the extremely convenient quality-price ratio. All these show a positive perception of the majority of tourists regarding the visited destination, being materialised in an increased flow of visitors and the beneficial effects on the local economy and the preservation of the mountain areas.
\end{abstract}

\section{Key words}

Bihor tourist destination - tourists' perception - tourist consumer habits $\cdot$ mountain tourism

\section{Introduction}

According to several authors, the mountains are places that despite the widespread globalisation of the contemporary world, still enjoy a pristine nature, undisturbed by the harmful human intervention (Boller et al., 2010; Ilieș et al., 2017; Gianchino et al., 2019; Linc et al., 2019). Other authors point out that these areas are very crowded due to human 
intervention, which leads to inadequate infrastructure development, over-construction, destruction of forests, etc. (Streifeneder \& Omizzolo, 2017; Vidović \& Dželetović, 2019; Abellán \& Martinez, 2021). One thing is for sure, over the years, the mountain areas have suffered intense metamorphosis to satisfy the ever-changing requirements (Bonadonna et al., 2017; Petrikovičová et al., 2019); thus, they have transformed from important areas of exploitation of natural resources into areas where tourism plays a key role (Ritchins et al., 2016). Due to their aesthetic beauty, natural and cultural landscapes that harmoniously intertwine (Więckowski, 2020), various possibilities to spend leisure time and the aura of mystery (Hull, 2016), the moutains attract millions of tourists each year. Considering the extended mountain area (approximately 24\% of the worldwide land surface) (Ritchins et al., 2016), the mountain tourism emerges as the second type of tourism in terms of popularity (after coastal tourism) registering 15-20\% of the total annual tourism and generating revenues of approximately $\$ 70-90$ billion annually (Keller, 2014). In addition to its high attractiveness to tourists, mountain tourism represents a very important global industry for economy (Favre-Bonte, 2019), playing a crucial role in the preservation of mountain areas and the traditional lifestyle of the native people (Jurigova \& Lencsesova, 2015; Kuščer et al., 2016; Mutana \& Mukwada, 2018).

Romania is a country which fulfils all the conditions to become a top destination for moutain tourism in Europe (Herman et al., 2019a; Więckowski \& Saarinen, 2019); approximately $28 \%$ of the total surface is occupied by the Carpathian Mountains (Cernaianu \& Sobry, 2017; Ilieș et al., 2017), with heights ranging between 600 and $2500 \mathrm{~m}$ and an average of $840 \mathrm{~m}$ (Posea, 2005). Although the mountain tourism has experienced a significant boom over the last two decades, by the proportional increase in the supply and demand, this type of tourism is still little developed, its contribution to the country's Gross Domestic Product (GDP)
(2.5\%) being almost insignificant (Brătucu et al., 2017). In this respect, the development and promotion of Romanian mountain tourism at national and regional level represents a target that is imperative in order to enhance its competitiveness.

In this context, with the development of mountain tourism it is necessary to know the tourists' perception regarding the targeted area as decision-making support in the development of sustainable tourism, in accordance with the need of the tourist demand (Drăghici et al., 2015; Toral et al., 2018; Grecu et al., 2019; Dehoorne et al., 2019).

In an extremely competitive environment, as it is tourism nowadays, the success of a destination may be in close relation with knowing the tourists' perception as main beneficiaries, being an important support for the innovations meant to attract a higher number of prospective visitors (Araujo et al., 2018).

The conduct of this study aims at knowing the perception of tourists from "Bihor Mountain Tourist Destination, Romania". This was possible by obtaining a real scanning from the perspective of the need for tourist demand that cannot be overlooked by the tourist offer. Among the requirements of the demand, special attention was given to knowing the tourist information, in close relation with the habits of the prospective tourists regarding services of accommodation, number of overnight stays and frequency of travelling, as well as the favourite type of tourism. The assessment of tourist satisfaction regarding the accommodation and food services in Bihor Mountain destination, in the quality-price ratio, compared to other visited tourist destinations, has represented an important element in this study, serving to identify the potential conflicts between supply and demand. At the same time, we tried to answer the following questions: "What is the perception of tourists regarding Bihor Mountain tourist destination?"; "What is the degree of knowledge of the area analyzed from the perspective of the interviewed tourists"; "What are the 
consumer habits of tourists?" and "What is the perception of quality-price ratio".

The working hypothesis used as a starting point for this study concerns the fact that the tourists' perception is reflected in the consumer behaviour in tourism, in the intention and decision to visit and revisit a given tourist destination and indirectly, in strengthening the image of tourist destination (Dwivedi, 2009; Lv \& McCabe, 2020).

The image of tourist destination is an extremely important variable with direct influence in the genesis, evolution and dynamic of tourism in a given area (Chaudhary, 2000; Moon \& Han, 2019; Duan et al., 2020). Shaping and strengthening the image of tourist destination require resources and perseverance from all the stakeholders in the management of tourist destinations (Czernek-Marszałek, 2019; Herman et al., 2019a). In this context, the tourists (as main beneficiaries) and the way in which they perceive the destination area have an important contribution (as main beneficiaries)
(Beerli \& Martı́n, 2004; Cracolici \& Nijkamp, 2009; Zhang et al., 2018; Toral et al., 2018). It is well-known the fact that the tourists' perception represents a quality indicator of the tourist destinations, extremely complex, involving a wide range of variables, sometimes difficult to capture in expert studies. Against this background, this study aims at creating a template to quantify the tourists' perception regarding "Bihor Mountain Tourist Destination, Romania". Therefore, this study stands out as a necessity. The knowledge of the tourists' perception contributes to the strategic decision-making process regarding the development of the analysed mountain destination in accordance with the tourists requirements and desires, without neglecting other issues related to the social (Dezsi et al., 2014; Szromek et al., 2020), economic (Drăghici et al., 2015; Stepanova, 2019) and ecological purpose (Stepanova, 2019; Wendt et al., 2019; Widawski et al., 2020) of tourism.

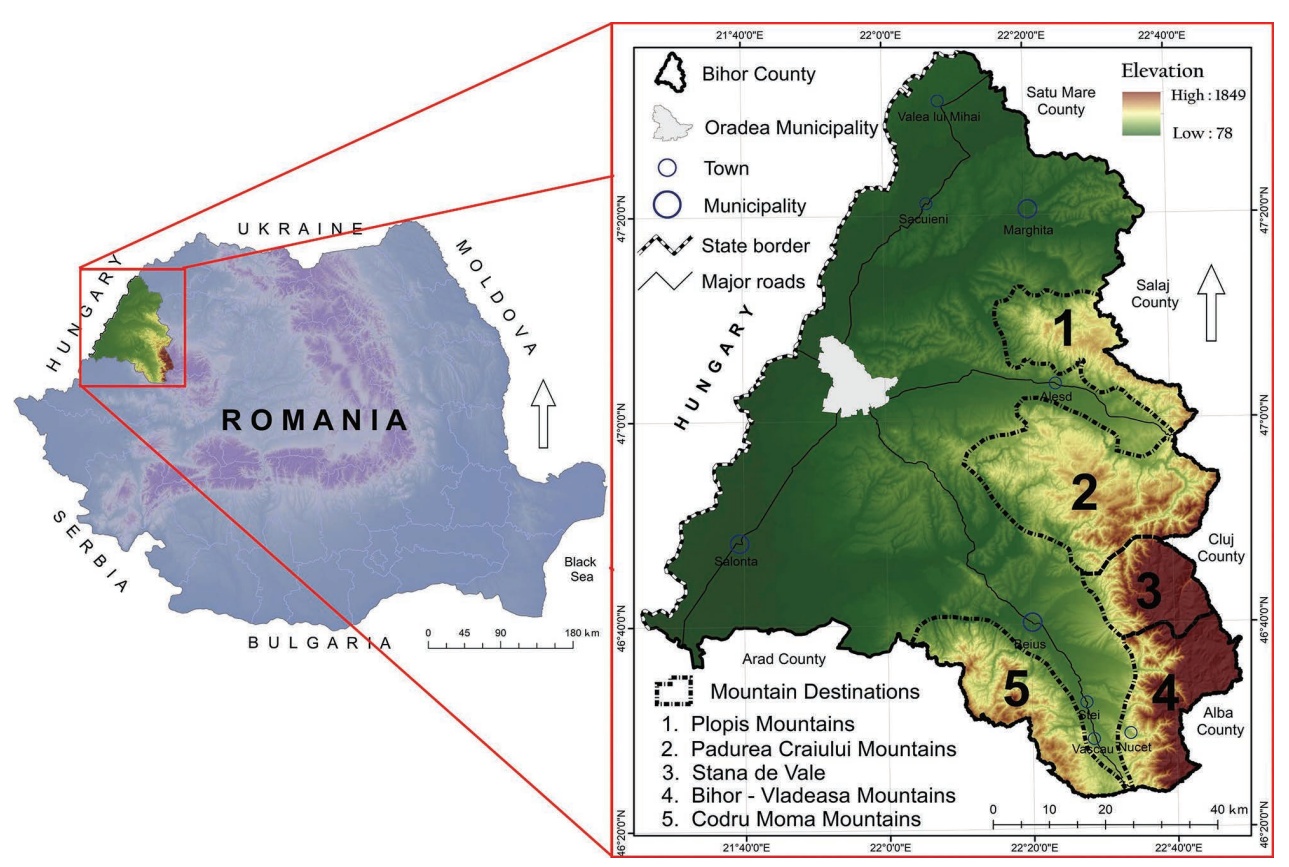

Figure 1. The location of the studied area 


\section{Work methodology}

\section{Study area}

Bihor mountain destination, located in the north-western part of Romania, in the county with the same name, on the western border with Hungary, is a special geographic area in which nature and man have cohabited since ancient times, their interraction giving rise to several elements with obvious tourism features. The proximity of the Romanian-Hungarian state border can represent a dynamizing element for cross-border tourism, especially for Hungarian tourists, with direct effects in completing and diversifying the possibilities of spending leisure time in mountain areas. Structurally, Bihor Mountain destination can be divided in five sub-destinations as folows: Pădurea Craiului, Stâna de Vale, Plopiş Mountains, Bihor-Vlădeasa Mountains and Codru Moma Mountains (Fig. 1), each having unique characteristics and features with implications in the genesis, dynamics and function of mountain tourism (Herman et al., 2019b).

Bihor mountain area is one of the emergent spaces with real possibilities for developing mountain tourism, being defined by the existence of numerous unique tourist attractions, some natural and others man-made over time, as an expression of his communion with nature. In this area, more than anywhere else, it is noticeable the close relationship between man and nature, reflected by some buildings that are representative for the local communities and the site-specific identity. Among these, we note: the wooden churches considered monuments (over 20 units); the stonewall churches considered monuments; craft workshops etc. From the natural attractions we mention: caves (the tourist ones - Bears' Cave, Meziad Cave, Crystal Cave inside Farcu mine, Ungurul Mare Cave and Vadu Crișului Cave and speleological caves - Vântului Cave, Bătrânului, Ciur-Ponor, Craiului, Doboș, Gălășeni, Gruiețului, Hârtopul Bonchii, Moanei and Osoi); karst plateau (Padiș; Runcuri, Zece Hotare and Damiş-
-Ponoraș); gorges (Albioarei, Brătcuței, Cuților, Lazuri, Videi, Mișidului, Sighiștelului, Sohodolului etc.); the waterfalls on Boiului valley (Boiului Waterfall) and Crișului valley (Vadu Crişului Waterfall) etc.

\section{Data analysis}

The data necessary to carry out this study was obtained within the timeframe July-August 2019, in various locations within Bihor Mountain Destination, using the sociological survey method based on questionnaire (Chelcea, 2007; Bryman, 2012; Bar et al., 2016; Wendt et al., 2019). The methodology that was used had implied consulting tourists by making use of the questionnaire method regarding "The Perception of Bihor Tourist Destination".

Structurally, the questionnaire was made of eleven items referring to: the degree of knowledge of Bihor tourist destination and how the information is disseminated; the tourists consumer habits regarding the accommodation facilities, number of overnight stays, the frequency of product and tourist consumer services and the type of tourism practiced; the perception of the quality-price ratio in Bihor tourist destination. Furthermore, in the questionnaire emphasized socio-demographic information relevant for tourism: namely nationality, gender, age, level of education, foreign languages spoken. The information rgarding the perception of Bihor tourist destination was obtained by consulting 135 people.

In outlining the socio-demographic profile of the respondents, the following analytical issues were taken into consideration: nationality, gender, age, level of education and foreign languages spoken. 54 (40\%) females and 81 (60\%) males, over 18 years old, took part in this study. From the analysis of the respondents classified by age groups, it was noticed that the largest share was held by the groups of persons aged between $36-45$ years old (38.5\%), 46-55 years old (38.5\%) respectively, followed by those between $26-35$ years old (14.1\%), 56-65 years old $(7.4 \%)$, over 65 years old $(0.7 \%)$ 
and $18-25$ years old (0.7\%). Regarding the level of education, it was noted that 72 people (53.3\%) have secondary education, while 64 people (47.4\%) have university degree. The analysis of how communication is achieved shows that English is ranked first (60.7\%), followed by Hungarian (24.4\%), German (23\%), French (17.8\%) and others (2.2\%). Ethnically, the Romanians prevail with $70.4 \%$ (95 people).

In terms of methodology, in order to quantify the tourists' perception regarding the image of tourist destination in Bihor mountain area, Romania, the maximum results were used, in percentages (\%), from six items in the questionnaire applied to tourists, two items for each of the three analysed aspects: the degree of knowledge; the tourists' consumer habits; the perception of quality-price ratio.

\section{Results and discussions}

Based on these percentage values it was established a value scale related to the perception of the analysed mountain tourist destination, ranging from $0 \%$ to $25 \%$ (very week); $26 \%$ to $50 \%$ (week); $51 \%$ to $75 \%$ (good); $76 \%$ to $100 \%$ (very good) (Tab. 1, Fig. 11).

\section{The degree of knowledge of Bihor Mountain tourist destination}

Information is a fundamental premise in tourism which is vital in outlining and promotion the image of tourist destination. Tourists also have an important contribution in the consolidation and dissemination of the image of tourist destination by means of emission - reception function of the information (Herman et al., 2020).

The tourists interviewed in this study are people who have had a certain experience in Bihor tourist destination; thus, from a total of 135 people, 114 (84.4\%) stated that they have visited this area before. In consequence, the accuracy and precision of the answers are significantly higher; the tourists have already a well-defined image of the tourist destination.

The analysis of the answers given to the first question "Which are your favourite tourist

Table 1. Quantifying the tourists' perception in Bihor Mountain destination, Romania

\begin{tabular}{|c|c|c|c|c|c|c|c|}
\hline \multirow{3}{*}{ Nr. } & \multirow{3}{*}{\multicolumn{2}{|c|}{ Criteria used to outline the perception }} & \multicolumn{4}{|c|}{ The value of the perception } & \multirow{3}{*}{$\begin{array}{l}\text { The value } \\
\text { of the per- } \\
\text { ception }\end{array}$} \\
\hline & & & \multirow{2}{*}{\begin{tabular}{|c|} 
very weak \\
$0 \%-25 \%$
\end{tabular}} & \multirow{2}{*}{$\frac{\text { weak }}{26 \%-50 \%}$} & \multirow{2}{*}{$\frac{\text { good }}{51 \%-75 \%}$} & \multirow{2}{*}{\begin{tabular}{|l|} 
very good \\
$76 \%-100 \%$
\end{tabular}} & \\
\hline & & & & & & & \\
\hline 1 & $\begin{array}{l}\text { The degree } \\
\text { of knowledge }\end{array}$ & The favourite tourist destinations & - & - & - & $98.5 \%$ & Very good \\
\hline 2 & & Tourist promotion materials & - & - & $73.3 \%$ & - & Good \\
\hline 3 & The tourists' & The number of overnight stays & - & - & $60.7 \%$ & - & Good \\
\hline 4 & $\begin{array}{l}\text { consumption } \\
\text { habits }\end{array}$ & The frequency of tourists' travels & - & - & $54.1 \%$ & - & Good \\
\hline 5 & $\begin{array}{l}\text { The perception } \\
\text { of quality-price } \\
\text { ratio }\end{array}$ & $\begin{array}{l}\text { The perception of accommoda- } \\
\text { tion and food services in Bihor } \\
\text { Mountain destination in terms } \\
\text { of quality-price ratio in relation } \\
\text { to other visited tourist destina- } \\
\text { tions }\end{array}$ & - & $43 \%$ & - & - & Weak \\
\hline 6 & & $\begin{array}{l}\text { The value of the sums available } \\
\text { to be spent by the respondents } \\
\text { during one holiday }\end{array}$ & - & - & $51 \%$ & - & Good \\
\hline \multicolumn{3}{|c|}{$\begin{array}{l}\text { Total } \\
380.6 / 6=63.4\end{array}$} & 0 & 43 & 239.1 & 98.5 & $\begin{array}{l}\text { Good } \\
63.4 \%\end{array}$ \\
\hline
\end{tabular}


destinations in Bihor County?" has emphasised the respondents' preference for the mountain area $(98.5 \%, 133$ people), followed by Băile Felix - Băile 1 Mai (38.5\%, 52 people) and Oradea (6.7\%, 9 people) (Fig. 2). This fact shows that the mountain tourist has little interest in the other destinations in Bihor County, except for Băile Felix - Băile 1 Mai and Oradea. However, the information acquired is essential in the process of making the strategy for the integrated capitalization of Bihor Tourist Destination. This information is then linked with similar information provided by the tourists from the other destinations. For example, the tourists from Băile Felix - Băile 1 Mai destination were interested in Bihor Mountain Destination at a share of $45 \%$.

The spatial concentration of the tourist attractions and the possibilities of accessing them have led to a tourist mental division of the mountain area into four tourist subdestinations: Vârtop, Stâna de Vale, Padiș and Pădurea Craiului. Each is characterised by certain particularities: Vârtop offers optimum conditions for practising winter sports; Stâna de Vale focuses on physical and psychological recovery and rehabilitation; Pădurea Craiului represents a destination focused on ecotourism; Padiș is famous for the karst relief and its tourist attractions.

Within Bihor Mountain tourist destination it is noticeable a preference for Bears' Cave, Stâna de Vale and Meziad Cave. Special attention was paid to the other attractions, in order of preference: Padiș Karst Plateau, Vârtop Holiday Village, Sighiștelului Gorges and Boga Valley (Fig. 3).

A considerable contribution was represented by the tourists' experiences in Bihor Mountain destination and the tourism promotion actions carried out especially online, at the level of public and private stakeholders.

The analysis of the answers offered to the question "Has the promotion of Bihor mountain area influenced you in chosing your holiday destination?" shows that this space receives a certain segment of well-informed tourists ( $80 \%, 108$ people) who were not influenced by the promotion actions when deciding to spend their holiday in Bihor mountain area. The share of those who were influenced (20\%), can be easily related to the share of people who travelled in Bihor for the first time (15.6\%). As a consequence, we consider that the tourist promotion actions are extremely useful to attract and retain new tourists focused on practising mountain tourism.

With regard to information sources, it is obvious that a stronger emphasis should be placed on the online, $73.3 \%$ declaring that they took their information online before taking the decision to travel to Bihor mountain area. The printed materials and the opinion of friends'/relatives' have also contributed significantly in taking the decision of tourist consumer (20.7\%), while on the opposite side were situated the other forms of promotion among which promotion of the destination

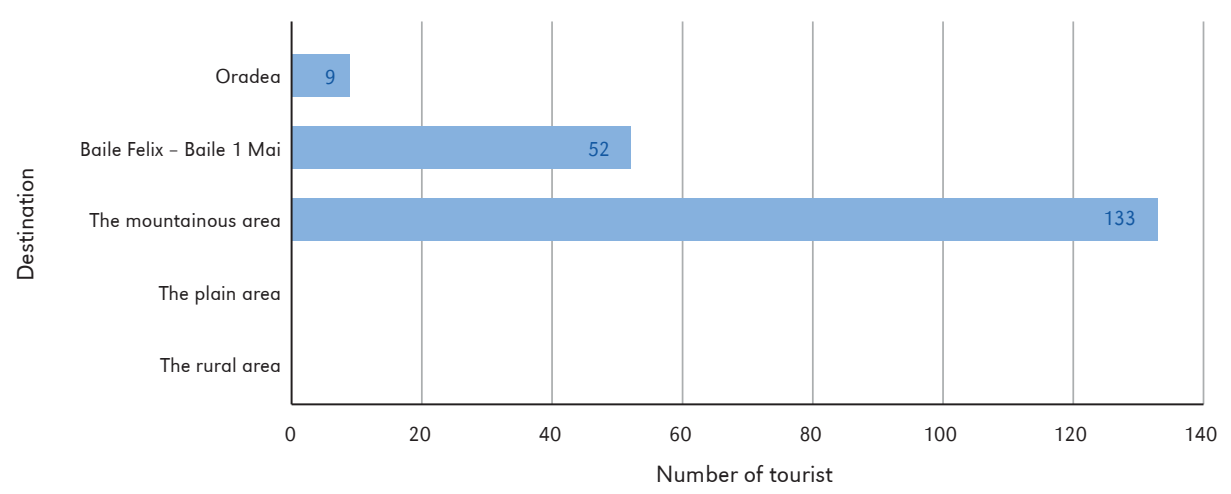

Figure 2. The favourite tourist destinations in Bihor County 


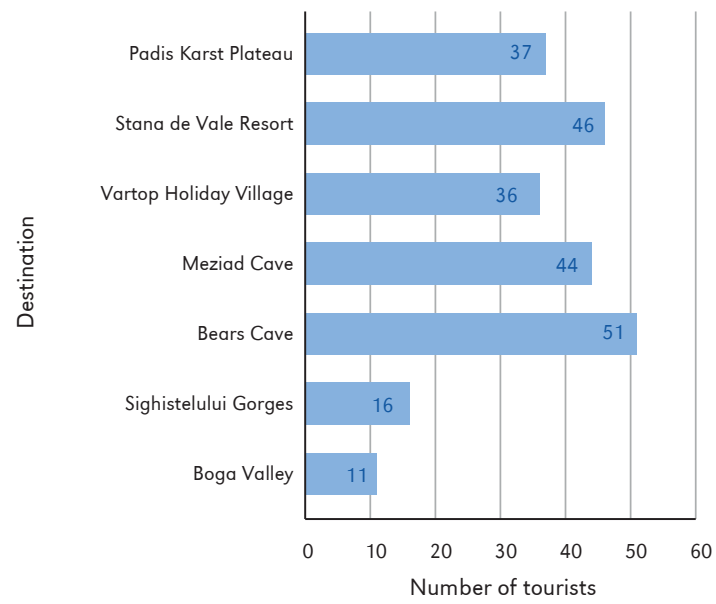

Figure 3. Favourite tourist destinations from Bihor Mountain area

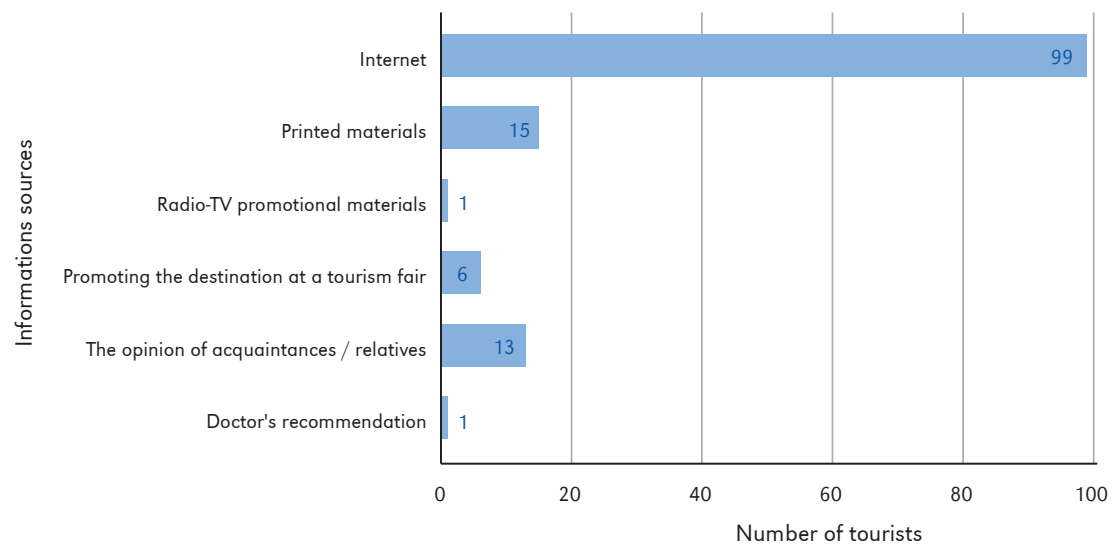

Figure 4. The sources used by the respondents regarding Bihor Mountain area

at tourist fairs, radio and TV broadcasting, etc. (Fig. 4).

\section{The tourists' consumer habits}

In the category of consumer habits were analysed several issues regarding the tourists behaviour related to transportation services, accommodation services, number of overnight stays, the frequency of consumption and the favourite type of tourism.

The particular physical and geographical conditions and the degree of endowment of the transport infrastructure have contributed to the tourists' unanimous decision to travel to the mountain destination by their own cars or by coach. The access to Bihor mountain destination is done via Beiușului depression, located in the south-eastern part of Bihor county, upstream on Crișul Negru river, along DN76 / E79 road, between Codru Moma Mountains in the south-west and Bihorului Mountains in the north-east. The distances between Bihor mountain destination and the nearest urban centers, which may be established as tourist reception centers are: 90 km Oradea, 132 km Deva, 142 km Cluj Napoca and $170 \mathrm{~km}$ Arad.

Regarding the accommodation services, we note that the interviewed respondents have preferred the accommodation in the tourist guesthouses (48.1\%, 65 people), 
followed by hotel units $(26.7 \%, 36$ people), tourist villas (8.1\%, 11 people), etc. (Fig. 6).

In Bihor mountain destination, in 2019, the accommodation facilities were represented by 101 units with accommodation function (2331 places), distributed percentage-wise as follows: tourist guesthouses (65.4\%), tourist chalets (7.9\%), hotels (7.9\%), tourist villas (5\%), camping sites (4\%) and other categories (19.8\%) (Fig. 5A), while the existent accommodation capacity in 2019 indicates that the majority of accommodation places were in the tourist guesthouses (972 places, 41.7\%), followed by hotels (447 places, 19.2\%), tourist chalets (259 places, $11.1 \%$ ), camping sites (130 places, 5.6\%), tourist villas (102 places, $4.4 \%)$ and other types of structures (421 places, 18.1\%) (Fig. 5B).

The analysis of the number of overnight stays has shown that the largest share of tourists usually spend 2-3 days (60.7\%, 82 people), 4-5 days (32.6\%, 44 people), respectively. The share of those who stay more than five days is $5.2 \%$ (7 people), while
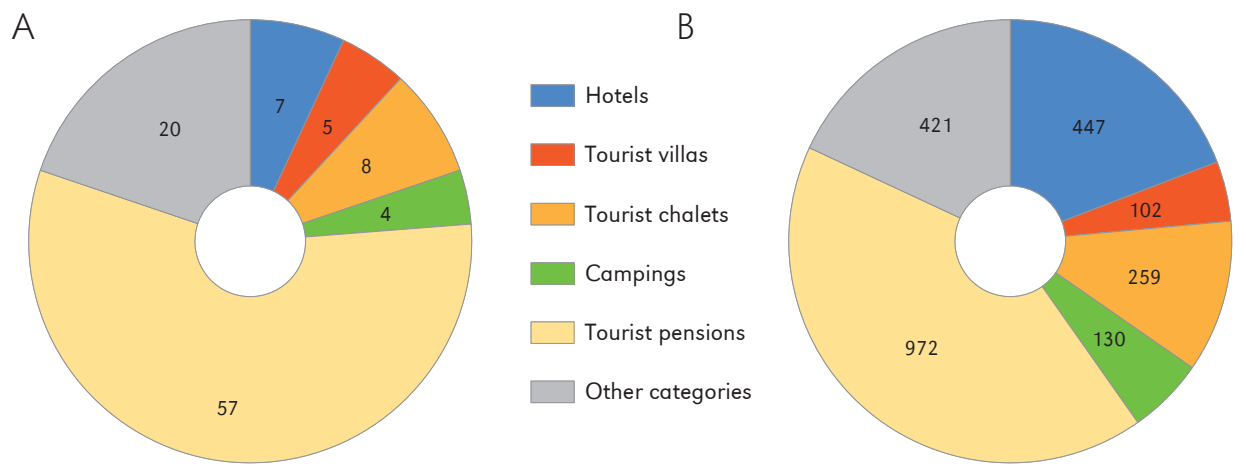

Figure 5. The share of tourist structures with accommodation function in Bihor mountain area in 2019. A. Number and share of tourist accommodation structures; B. The existent tourist accommodation capacity according to the types of accommodation structures (Data source: Ministry of Tourism, Tourist accommodation structures with classified accommodation functions, 2019)

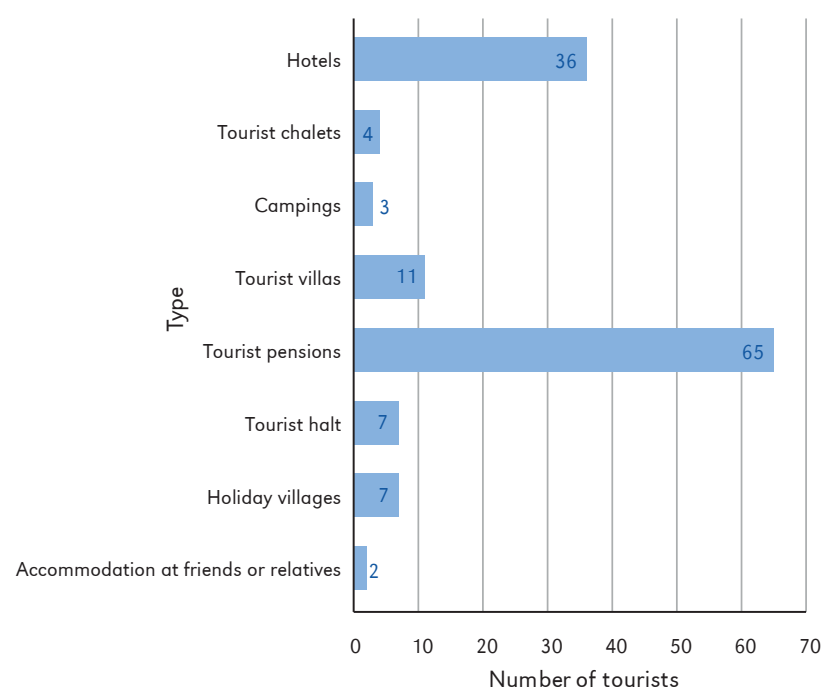

Figure 6. Tourist accommodation habits in Bihor mountain area 
the share of those who stay only one day is $1.5 \%$ (2 people) (Fig. 7).

The analysis of the frequency of travels for tourist reasons classified according to value groups has emphasised the category of tourists who travel three times a year (54.1\%, 73 people), followed by those who travel twice a year (25.9\%, 35 people), several times a year $(16.3 \%, 22$ people) and once $(3.7 \%$, 5 people) (Fig. 8).

Recreational tourism is the type of tourism preferred by tourists in Bihor mountain destination (100\%).
$15.6 \%$ of the respondents were here for the first time), the information regarding the sums of money that tourists would be willing to spend on tourist consumer in Bihor mountain destination is extremely interesting. The amount of money tourists would be likely to spend on a holiday (three days with two nights per person) is a significant indicator in determining the short-term tourism marketing strategies and sizing tourist facilities. Therefore, the analysis of the indicator "the amount of money available to spend" has emphasised the existence of four typical

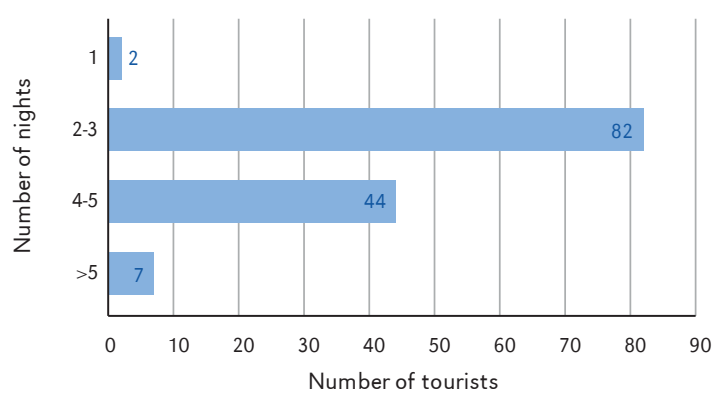

Figure 7. The number of overnight stays in Bihor mountain area

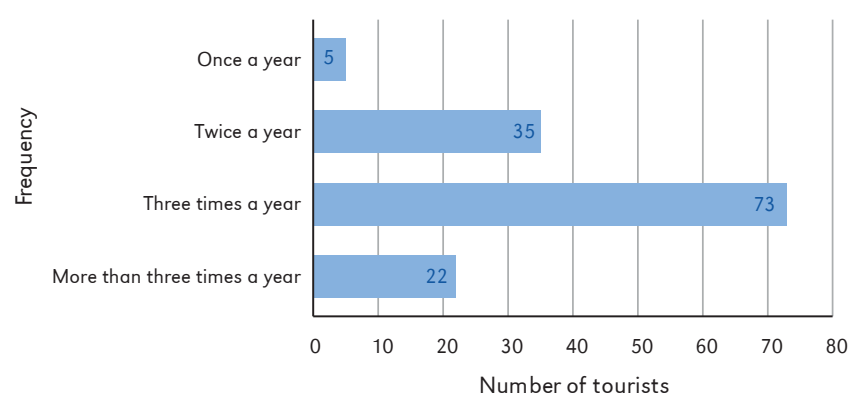

Figure 8. The frequency of tourists' travels in Bihor mountain area

\section{The perception of quality-price ratio}

The ratio between the quality of delivered services and their price is a very important trait on a tourism market where the key word is 'competitiveness', this aspect being closely linked to the success or failure of a tourist destination.

Taking into account the tourists' various experiences in Bihor destination (only categories of tourists, willing to spend amounts ranging between: 1000 and 2000 RON (43\%, 58 people); 500-1000 RON (27.4\%, 37 people); 2000-5000 RON (24.4\%, 33 people) and under $500 \operatorname{RON}(5.2 \%, 7$ people) (Fig. 9). We mention that between July and August 2019, when the respondents were consulted, the average net salary in Romania was 3044 RON, respectively 644.9 EURO (National Institute of Statistics, 2019). 
$\mathrm{RON}$ is the Romanian currency. $1 \mathrm{RON}=0.21$ Euro / 1 Euro $=4.72$ RON (National Bank of Romania).

Considering the above-mentioned information, we can outline the profile of the tourist who is willing to spend money between 1000 and 2000 RON. Compared to the level of prices charged within the analysed space, we can say that we are dealing with a budget above expectations. It remains to be seen if the stakeholders in tourism, especially service providers, will be able to manage this trend, i.e., spending money from the tourists' part, by increasing the quality (of tourist products and services) and diversifying the options for spending leisure time.

Having certain experience, the majority of the respondents not being for the first time in Bihor mountain destination, they appreciate the accommodation and food services in relation to other tourist destinations that they have visited. Thus, all the interviewed tourists have classified the quality-price ratio related to the accommodation and food services in Bihor Mountain Tourist Destination as very good $(51 \%, 69$ people) and good (49\%, 67 people) (Fig. 10).

\section{Discussion}

Bihor mountain destination is a geographic area characterized by a large diversity of tourist attractions, both natural and anthropic, located in the south-east of the county, in North-West part of the country, orographically overlapping the mountain units Bihor - Vlădeasa, Pădurea Craiului Mountains, Codru Moma and Beiuș depression.

Regarding the study area, it has been the subject of many studies and research

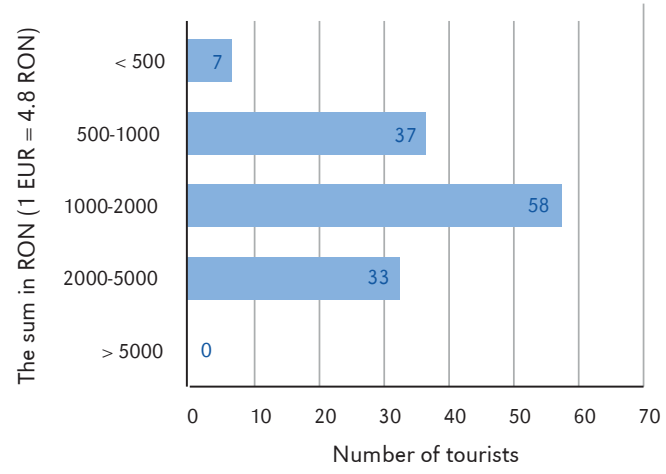

Figure 9. The value of the amounts available to be spent by the respondents in one holiday in Bihor mountain area

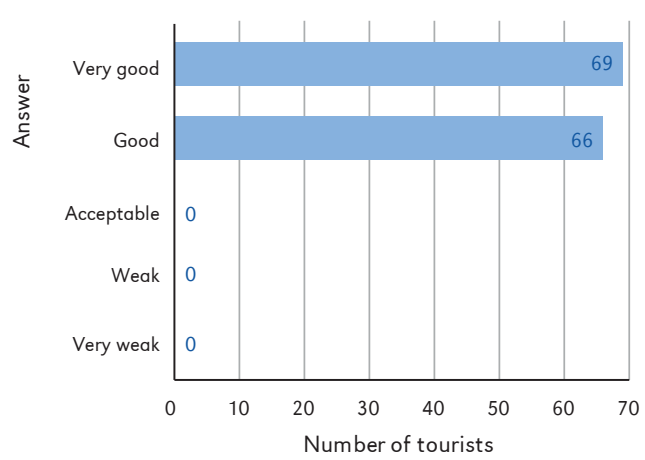

Figure 10. The perception of accommodation and food services from Bihor mountain destination in terms of quality-price ratio in relation to other visited tourist destinations 
on tourism and its economic, social and ecological implications. Among these, we mention the paper "Transport Infrastructure and Political Factors as Determinants of Tourism Development in the Cross-Border Region of Bihor and Maramureș. A Comparative Analysis", drafted by Wendt et al., 2021. It aims to determine the existence of correlations "the development of the transport network and the increase in tourist traffic" (Wendt et al., 2021). The results obtained have revealed that transport infrastructure has a critical part in ensuring connections between border regions. We mention that the studied area was analyzed extensively from the perspective of the tourist potential (Herman et al., 2019b) and ways to quantify it (Dehornee et al., 2019).

Tourism is an extremely complex and competitive activity with clear economic, social and ecological implications. In this respect, knowing the tourists' perception along with other aspects equally important, such as knowing the perception of the local community and more, represents an important concern of all the factors involved in the development of Bihor Mountain Tourist Destination. To this end, in this study we have developed a methodology to quantify the perception. We mention that this is not perfect; it has some drawbacks among which the means of quanti- fication and the low number of variables taken into consideration. Despite these drawbacks, the results achieved can provide a strong decision and information support for all the factors involved in the effort to strengthen and promote the image of a tourist destination.

\section{Conclusions}

The analysis of the tourists' perception regarding Bihor mountain tourist destination in Romania has emphasised the existence of some malfunctions concerning the indicator "The perception of accommodation and food services in Bihor mountain destination in terms of quality-price ratio related to other visited tourist destinations" whose maximum value was 43\% (weak), while for the indicator "The favourite tourist destinations" the maximum value was $98.5 \%$ (very good). The other indicators fell within the values ranging between 51\% and 75\% (good) (Tab. 1, Fig. 11).

Following the quantification of the tourists' perception regarding Bihor mountain tourist destination in Romania, in accordance with the developed methodology, it was concluded that it is good, having a value of $63.4 \%$. This has resulted from reporting the total score ( 380.6 percentages) from the 6 analysed indicators.

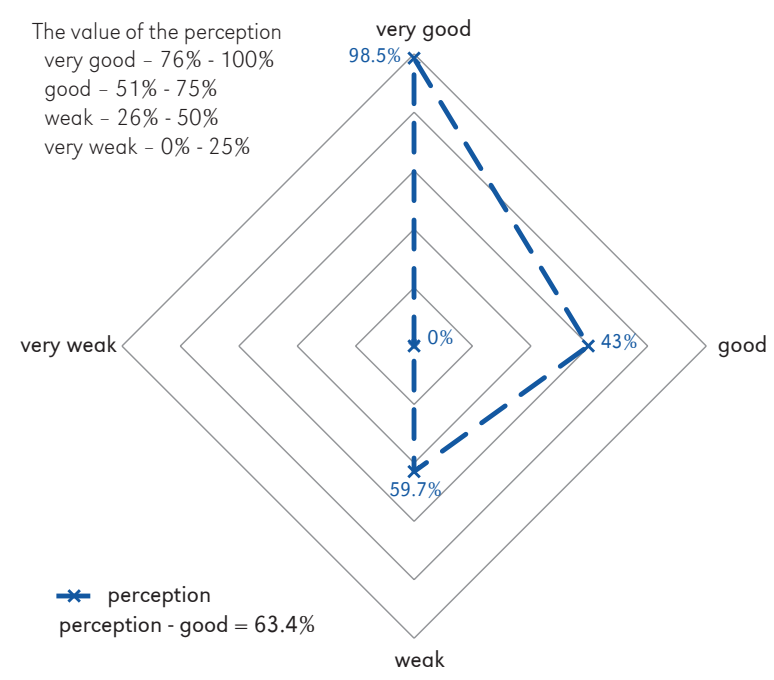

Figure 11. The perception of Bihor mountain destination 
The analysis of the degree of knowledge reveals the fact that Bihor Tourist Destination is a destination known by the tourists; they have not come here for the first time (84.4\% of the interviewed tourists). They prefer to come back in order to visit the following sites: Bears' Cave, Stâna de Vale, Meziad Cave, Padiș Karst Plateau and Vârtop (Fig. 3). $38 \%$ of the interviewed people have stated that besides Bihor Mountain Destination, they also prefer Băile Felix-Băile 1 Mai destination (Fig. 2). This information linked to the information obtained in the above-mentioned destination (by performing a similar survey in which the item regarding the tourists' preferences for other tourist destinations in Bihor scored a value of $45 \%$ ) can be used startegically in setting up some complex spa-mountain tourist packages, taking into account the fact that the distance between the two destinations (Băile Felix - Băile 1 Mai Spa Destination and Bihor Mountain Destination) is short $(90 \mathrm{~km})$ and the access is easy, DN76 road being recently rehabilitated (2020). The sources used by the respondents before going to the destination area have emphasised the importance of the online (Fig. 4). It is noticeable the relatively low share (4\%) of replies regarding the importance of tourism fairs. This information can be linked with the information related to the financial effort made in this respect by the central and regional public authorities in order to underline the role and importance of promoting tourism through tourism fairs.

The tourists' consumer habits have targeted vital aspects regarding transport, accommodation, length of overnight stays and the frequency of travelling in the studied area. Regarding the means of transport, tourists have chosen $100 \%$ road transport, the majority coming from urban areas from the immediate proximity of the analysed mountain area. As for the preferred accommodation units, on typological categories, we have noticed the preferences for tourist guesthouses (48.1\%), followed by hotel units $(26.7 \%)$ and tourist villas (8.1\%). The comparative analysis of the values of preferences regarding the form of accommodation and accommodation capacity reveals some differences in percentages. These differences can represent valuable information of strategic nature towards adjusting the local accommodation supply to the demand. Therefore, it is obvious the need to increase the accommodation capacity of tourist guesthouses (6.4\% places), hotels (7.5\%) and tourist villas (3.7\%). The number of overnight stays $(60.7 \%$ of the tourists staying between 2 and 3 days) is an indicator that provides indirect information on the retention capacity and type of tourism (in terms of time) for which the analysed tourist destination is suitable (Fig. 7). The relatively high frequency of tourists that come back $(54,1 \%$ return three times a year) is directly linked with the tourists' degree of satisfaction in the destination area (Fig. 8) and also with the perception of the quality-price ratio, $51 \%$ of the respondents perceiving this ratio as a very good one (Fig. 10). Against this background, the amounts of money that the interviewed people would have been ready to spend on holiday (three days with two overnight stays) range between 500 RON and over 5000 RON. The most important share (71\%) belongs to the segment of tourists willing to spend between 1000 and 2000 RON (Fig. 9).

Considering the above mentioned information, we can state that the tourists' perception regarding the tourist destination is an important strategic variable that can be used for the sustainable development of tourism in Bihor Mountain Tourist Destination.

\section{Acknowlegements}

The research was possible by equal scientific involvement of all authors. The authors wish to thank to anonymous reviewer for the thoughtful suggestions and comments and to acknowledge the support of Bihor Destination Management Agency.

\section{Editors' note:}

Unless otherwise stated, the sources of tables and figures are the authors', on the basis of their own research. 


\section{References}

Abellán, F.C., García Martínez, C. (2021). Landscape and tourism as tools for local development in midmountain rural areas in the Southeast of Spain (Castilla-La Mancha). Land, 10(2), 221. https://doi.org/10.3390/land10020221

Araújo, A., Cardoso, L., Araújo, N., Dias, F. (2019). Understanding the role of destination imagery in mountain destination choice. Evidence from an exploratory research. European Journal of Tourism Research, 22, 151-165.

Bar, R., Tătar, C.F., Herman, G.V. (2016). Satisfaction degree rating of tourist services in Buziaș spa, Timiș County, Romania. GeoJournal of Tourism and Geosites, 18(2), 212-223.

Beerli, A., Martín, J.D. (2004). Tourists' characteristics and the perceived image of tourist destinations: A quantitative analysis - a case study of Lanzarote, Spain. Tourism Management, 25(5), 623-636. https://doi.org/10.1016/j.tourman.2003.06.004

Boller, F., Hunziker, M., Conedera, M., Elsasser, H., Krebs, P. (2010). Fascinating remoteness: The dilemma of hiking tourism development in peripheral mountain areas. Mountain Research and Development, 30(4), 320-331.

Bonadonna, A., Giachino, C., Truant, E. (2017). Sustainability and mountain tourism: The Millennial's perspective. Sustainability, 9(7), 1219. https://doi.org/10.3390/su9071219

Brătucu, G., Băltescu, C.A., Neacșu, N.A., Boșcor, D., Țierean, O.M., Madar, A. (2017). Approaching the sustainable development practices in mountain tourism in the Romanian Carpathians. Sustainability, 9, 2051. https://doi.org/10.3390/su9112051

Bryman, A. (2012). Social research methods: 4th edition. Oxford, USA: Oxford University Press.

Cernaianu, S., Sobry, C. (2017). The development of winter sports tourism in Romania - A historical approach. European Journal of Tourism Research, 16, 8-18.

Chaudhary, M. (2000). India's image as a tourist destination - a perspective of foreign tourists. Tourism management, 21(3), 293-297. https://doi.org/10.1016/S0261-5177(99)00053-9

Chelcea, S. (2007). Metodologia cercetării sociologice. Metode cantitative și calitative. București: Editura Economică.

Cracolici, M.F., Nijkamp, P. (2009). The attractiveness and competitiveness of tourist destinations: A study of Southern Italian regions. Tourism management, 30(3), 336-344.

https://doi.org/10.1016/j.tourman.2008.07.006

Czernek-Marszałek, K. (2019). Applying mixed methods in social network research-The case of cooperation in a Polish tourist destination. Journal of Destination Marketing \& Management, 11, 40-52. https://doi.org/10.1016/j.jdmm.2018.10.004

Dehoorne, O., Varodi, M. O, Caciora, T. (2019). Tourist resources assesement in Pădurea Craiului Mountains. Folia Geographica, 61(2), 163-171.

Dezsi, S., Rusu, R., Ilies, M., Ilies, G., Badarau, A.S., Rosian, G. (2014). The role of rural tourism in the social and economic revitalisation of Lapus Land (Maramures County, Romania). Geoconference on Ecology, Economics, Education and Legislation, 2, 783-790.

Drăghici, C.C., Pintilii, R.D., Peptenatu, D., Comănescu, L.G., Sirodoev, I. (2015). The role of SPA tourism in the development of local economies from Romania. Procedia Economics and Finance, 23, 1573-1577. https://doi.org/10.1016/S2212-5671(15)00400-1

Duan, X., Marafa, L.M., Chan, C.S., Xu, H., Cheung, L.T. (2020). Measuring the gaps in the projected image and perceived image of rural tourism destinations in China's Yangtze River Delta. Sustainability, 12(12), 5121. https://doi.org/10.3390/su12125121

Dwivedi, M. (2009). Online destination image of India: A consumer based perspective. International Journal of Contemporary Hospitality Management, 21(2), 226-232.

https://doi.org/10.1108/09596110910935714 
Favre-Bonte, V., Gardet, E.,Thevenard-Puthod, C. (2019). The influence of territory on innovation network design in mountain tourism resorts. European Planning Studies, 27(5), 1035-1057. https://doi.org/10.1080/09654313.2019.1588856

Giachino, C., Truant, E., Bonadonna, A. (2019). Mountain tourism and motivation: Millennial students' seasonal preferences. Current Issues in Tourism, 23(19), 2461-2475. https://doi.org/10.1080/13683500.2019.1653831

Grecu, A., Gruia, A.K., Marin, M., Bănuță, M., Olteanu, C., Constantin, I., Drăghici, C.C. (2019). Specificity of sustainable structural dynamics of local economy in Romanian tourist resorts. Sustainability, 11(24), 7155. https://doi.org/10.3390/su11247155

Herman, G.V., Grama, V., Sonko, S.M., Boc, E., Băican, D., Garai, L.D., Blaga, L., Josan, I., Caciora, T., Gruia, K.A., Grecu, A., Peptenatu, D. (2020). Online information premise in the development of Bihor tourist destination, Romania. Folia Geographica, 62(1), 21-34.

Herman, G.V., Wendt, J.A., Dumbravă, R., Gozner, M. (2019a). The role and importance of promotion centers in creating the image of tourist destination: Romania. Geographia Polonica, 92(4), 443-454. https://doi.org/10.7163/GPol.0158

Herman, G.V., Varodi, M.O., Grama, V., Morar, C. (2019b). Geographical considerations regarding the tourist destination Pădurea Craiului Mountains. Analele Universității din Oradea, Seria Geografie, 29(1), 102-108. https://doi.org/10.30892/auog.291111-808

Hull, J.S. (2016). Wellness tourism experiences in Mountain Regions: The case of Sparkling Hill Resort, Canada. Mountain Tourism: Experiences, Communities, Environments and Sustainable Futures, $C A B I, 25-35$.

Ilieș, A., Ilieș, D.C., Tătar, C., llieș, M. (2017). Geography of tourism in Romania. In K. Widawski, J. Wyrzykowski (Eds.), The geography of tourism of Central and Eastern European countries. Springer, Cham. https://doi.org/10.1007/978-3-319-42205-3_9

Jurigova, Z., Lencsesova, Z. (2015). Monitoring system of sustainable development in cultural and mountain tourism destinations. Journal of Competitiveness, 7(1), 35-52. https://doi.org/10.7441/joc.2015.01.03

Keller, P. (2014). Mountainlikers: New trends of mountain tourism for the summer season. In 8th World Congress on Snow and Mountain Tourism, Andorra: Principality of Andorra.

Kuščer, K., Mihalič, T., Pechlaner, H. (2016). Innovation, sustainable tourism and environments in mountain destination development: A comparative analysis of Austria, Slovenia and Switzerland. Journal of Sustainable Tourism, 25(4), 489-504. https://doi.org/10.1080/09669582.2016.1223086

Linc, R., Șerban, E., Caciora, T. (2019). Poiana Ruscăi: One mountain and two monuments. Analele Universității din Oradea, Seria Geografie, 29(2), 146-157.

Lv, X., Mccabe, S. (2020). Expanding theory of tourists' destination loyalty: The role of sensory impressions. Tourism Management, 77, 104026. https://doi.org/10.1016/j.tourman.2019.104026

Ministry of Tourism (2019). Structurile de primire turistică cu funcțiuni de cazare clasificate (Tourist reception structures with classified accommodation functions)(LSPTC). Retrieved from http://turism.gov.ro/web/autorizare-turism/ [July, 2019].

Moon, H., Han, H. (2019). Tourist experience quality and loyalty to an island destination: The moderating impact of destination image. Journal of Travel \& Tourism Marketing, 36(1), 43-59. https://doi.org/10.1080/10548408.2018.1494083

Mutana, S., Mukwada, G. (2018). Mountain-route tourism and sustainability. A discourse analysis of literature and possible future research. Journal of Outdoor Recreation and Tourism, 24, 59-65. https://doi.org/10.1016/j.jort.2018.08.003

National Institute of Statistics (2019). Average monthly earnings. Retrieved from https://insse.ro/cms/ro/tags/comunicat-castig-salarial?page=2 [15 April 2021]. 
Petrikovičová, L., Krogmann, A., Fialová, D., Svorad, A. (2019). Intensive tourist-related urbanisation impacts on a mountain village: The case study of Vel'ká Lomnica in Slovakia. Geographia Polonica, 92(4), 395-408. https://doi.org/10.7163/GPol.0155

Posea, G. (2005). Geomorfologia României: relief- tipuri, geneză, evoluție, regionare (Geomorphology of Romania: Relief - types, genesis, evolution, regionalization), Second Edition revised and added. Bucharest: Romania de Maine Foundation Publishing House.

Ritchins, H., Johnsen, S., Hull, J. (2016). Overview of mountain tourism: Substantive nature, historical context, areas of focus. Mountain Tourism: Experiences, Communities, Environments and Sustainable Futures, $C A B I, 1-12$.

Stepanova, S.V. (2019). The Northern Ladoga region as a prospective tourist destination in the RussianFinnish borderland: Historical, cultural, ecological and economic aspects. Geographia Polonica, 92(4), 409-428. https://doi.org/10.7163/GPol.0156

Streifeneder, T., Omizzolo, A. (2017). The Dolomites UNESCO World Heritage: Visitors' mobility behaviour and acceptance of regulatory measures. Journal on Protected Mountain Areas Research and Management, 9, 93-97. https://doi.org/10.1553/eco.mont-9-sis93

Szromek, A.R., Kruczek, Z., Walas, B. (2020). The attitude of tourist destination residents towards the effects of overtourism - Kraków case study. Sustainability, 12(1), 228. https://doi.org/10.3390/su12010228

The National Bank of Romania (2019). BNR Course Archive. Retrieved from https://www.cursbnr.ro/arhiva-curs-bnr-2019-08-30 [15 April 2021].

Toral, S.L., Martínez-Torres, M.R., Gonzalez-Rodriguez, M.R. (2018). Identification of the unique attributes of tourist destinations from online reviews. Journal of Travel Research, 57(7), 908-919. https://doi.org/10.1177/0047287517724918

Vidović, N., Dželetović, M. (2019). Impact of tourism on economic development of serbian mountain areas. Tourism International Scientific Conference Vrnjačka Banja - TISC, 4(2), 382-397.

Wendt, J., Buhaș, R., Herman, G.V. (2019). Experience of the Baile-Felix tourist system (Romania) for the protection and promotion of the grey seal as a brend on the Hel Peninsular (Poland). Baltic Region, 11(1), 109-116. https://doi.org/10.5922/2079-8555-2019-1-8

Wendt, J.A., Grama, V., Ilieș, G., Mikhaylov, A.S., Borza, S.G., Herman, G.V., Bógdał-Brzezińska, A. (2021). Transport infrastructure and political factors as determinants of tourism development in the crossborder region of Bihor and Maramureș. A comparative analysis. Sustainability, 13(10), 5385. https://doi.org/10.3390/su13105385

Widawski, K., Oleśniewicz, P., Rozenkiewicz, A., Zaręba, A., Jandová, S. (2020). Protected areas: Geotourist attractiveness for Weekend tourists based on the example of Gorczański National Park in Poland. Resources, 9(4), 35. https://doi.org/10.3390/resources9040035

Więckowski, M. (2020). Natural heritage as a resource fot tourism development in the Polish Carpathians. Geografický Časopis, 72(3), 243-259. https://doi.org/10.31577/geogrcas.2020.72.3.12

Więckowski, M., Saarinen, J. (2019), Tourism transitions, changes, and the creation of new spaces and places in Central-Eastern Europe. Geographia Polonica, 92(4), 369-377. https://doi.org/10.7163/GPol.0154a

Zhang, H., Wu, Y., Buhalis, D. (2018). A model of perceived image, memorable tourism experiences and revisit intention. Journal of Destination Marketing \& Management, 8, 326-336. https://doi.org/10.1016/j.jdmm.2017.06.004 